Session

\title{
THE ROLE OF MORAL PHILOSOPHY IN PROMOTING ACADEMIC INTEGRITY AMONG ENGINEERING STUDENTS
}

\author{
Brian K. Etter ${ }^{1}$, Trevor S. Harding ${ }^{2}$, Cynthia J. Finelli ${ }^{3}$ and Donald D. Carpenter ${ }^{4}$
}

\begin{abstract}
Academic dishonesty is nothing new, yet it is particularly disturbing to find among engineering students, whose professional lives need to be guided by the highest ethical standards. Moral philosophy may illuminate some of the conditions for recovering a sense of the ethical for engineering students. Classical moral philosophers held that people belong to communities in ways that inform their sense of obligation. Recognition of these communities would make concrete the engineer's responsibility for the health, safety and welfare of the public. A further difficulty is that the primary community that students know is simply that of their peers in school or the workplace, which does not form a sufficient context for the sense of moral obligation inherent in the engineer's role. This paper seeks to define the moral obligation of the engineer using traditional moral philosophy and how this obligation might be translated into a more positive definition of success. It will also address means by which educators can help engineering students to better understand their moral obligation.
\end{abstract}

Index Terms - academic dishonesty, engineering ethics, professional behavior

\section{INTRODUCTION}

Based on research results, there is little doubt that cheating in engineering programs is a more common occurrence than in most other disciplines. Though the numbers vary considerably due to survey design, demographic differences and historical context, studies show consistently that the self-reported frequency of cheating in engineering is second only to business $[1,2,3]$.

While there are clearly immediate implications for the academic process when students cheat in college, we might be less concerned as a society if we could be certain that unethical behavior in college did not continue into the workplace. However, recent research suggests that academic dishonesty in college may very well be a strong predictor of unethical behavior in the workplace $[4,5,6]$. In all of these studies, students who reported engaging in academic dishonesty in college were more likely to report engaging in dishonest behavior in the workplace. These findings suggest that the cause of cheating cannot be purely situational but must instead be influenced by the individual's own attitudes and moral beliefs toward the behavior. If this is the case, can we rely upon professional codes of ethics to alter these attitudes and beliefs in newly graduated engineers such that their dishonest behavior does not continue?

Codes of ethics set common moral principles within the context of a specific professional domain. However, they are generally prescriptive and provide little rationale for why a particular course of action is the appropriate one for the individual [7]. The implied rationale within these codes is related directly to the idea of a moral obligation to one's community. However, as we will describe in this paper, today's students often lack an appropriate sense of community that will allow them to adequately interpret codes of ethics. Furthermore, resolving ethical dilemmas in professional practice has been shown to require professional knowledge that is developed only with experience [8]. Thus, it would seem that students are not only unprepared to understand the significance of codes of ethics, it may also require years of professional experience before they are able to do so.

The following paper seeks to define the engineer's moral obligation to the community by traditional moral philosophy. It will also describe how this definition of moral obligation can be used to generate a new concept for success in professional practice. Finally, it will provide practical suggestions for encouraging a sense of community within engineering education, institutions of higher education and the classroom to better prepare students to understand and adhere to codes of ethics in professional practice. In this endeavor, it will be important to recognize that philosophers write differently from scientists and engineers: their vocabulary and syntax may well seem almost a different language. Yet it is precisely this that reflects the crucial difference in perspective necessary for describing moral perspectives in a way that can promote integrity both in the classroom and the workplace.

\section{MORAL PHILOSOPHY AND INTEGRITY}

The most important of moral philosophers today, Alasdair McIntyre, has pointed to the necessity for a return to the construction of local communities in order to restore the possibility of a moral practice to our civilization. He argues that the characteristic mode of social organization in

\footnotetext{
${ }^{1}$ Brain K. Etter, Kettering University, Liberal Studies, Flint, MI 48504, better@kettering.edu

${ }^{2}$ Trevor Harding, Kettering University, Manufacturing Engineering, Flint, MI 48504, tharding@kettering.edu

${ }^{3}$ Cynthia J. Finelli, University of Michigan, Center for Research on Learning and Teaching, Ann Arbor, MI 48109

${ }^{4}$ Donald D. Carpenter, Lawrence Technological University, Southfield, MI 48075, carpenter@ltu.edu
} 


\section{Session}

modernity - the bureaucratic, hierarchical mode - leaves individuals adrift in a world without the framework necessary to provide a meaningful narrative of life. Hence, moral practice disintegrates as the individual finds the ties linking one to family and community are broken; once these defining ties disappear, the individual must construct his identity by himself. Then, the self becomes conceived in terms of an asocial dichotomy: what one does, and what one feels [9]. It is easy to see that as the maximization of pleasure becomes the goal of life, success in a career will be measured by the amassing of material goods. But such a goal places no premium on ethical behavior, either in the workplace or in the classroom. It is not surprising, therefore, to find academic dishonesty leading to professional misconduct.

McIntyre's analysis depends on a reconstruction of historical moral systems as recorded in the writings of philosophers from classical Greece through the medieval synthesis of Thomas Aquinas. Aristotle, for example, notes that man is not intended by nature to live a solitary life, but rather seeks the good life together with his parents, wife, friends, and fellow citizens, "since man is born for citizenship."[10] Indeed, one-fifth of his Nichomachean Ethics is devoted to an explicit discussion of friendship which, characteristically one modern editor cannot understand as being relevant to the main topic of the work, which is excellence of character [11]. Yet if McIntyre is right, excellence of character, or virtue, cannot be cultivated outside of such relations of friendship. To the extent that the modern world cuts the individual off from these defining bonds, neither virtue nor moral obligation will much matter. People will do anything they can get away with if it maximizes their chances for success.

Yet it is not clear that the Aristotelian model provides the best framework for discussing community and its importance for morality or ethics. For that, we need to turn to a philosopher from classical Rome, whom McIntyre does not much discuss, yet who has been more important even than Aristotle for the teaching of ethics and morality: Cicero. A statesman having held the highest offices of the Roman Republic, Cicero wrote his treatise On Duties as a desperate attempt to remind his fellow citizens of the foundations of honorable, moral behavior in a time of political corruption and the loss of political freedom under the dictatorship of Julius Caesar. In this treatise, Cicero makes an explicit connection between community, or "fellowship," as the context for all human existence and the existence of concrete moral obligations. His perception of the conditions for ethical behavior, therefore, differs substantially from both the prevailing views in our society and the view embodied in the NSPE Code of Ethics, which does not locate specific communities as the context for ethical conduct. Our argument, however, is that it should provide a salutary corrective for the teaching of ethical standards to engineering students, and in particular for the cultivation of academic integrity.
Cicero distinguishes four natural levels of fellowship. The first in priority, although the weakest in actuality, is that of the entire human race. But this arises not simply because we recognize the similarity of other individuals having two arms and two legs, but from the bonding of reason and speech, "which reconcile men to one another, through teaching, learning, communicating, debating and making judgements"[12]. Such a widespread community, nevertheless, entails specific moral consequences, for "we must preserve the communal sharing of all the things that nature brings forth for the common use of mankind." This means giving assistance whenever it can be done "without detriment" to oneself, not denying others access to fresh water, sharing fire with others, giving trustworthy advice - in short, being generous to others in a way that contributes to "the common benefit [13]". This concept of obligations to humanity in general, then, is not vague at all: we are clearly not to pollute our neighbors' water, and we are called upon to assist even the stranger. By contrast, it has taken major efforts in our modern world to control pollution by law, and even now there are still deep tensions between industry and environmental advocates on this issue: our sense of obligation is fragmented and abstract.

The NSPE Code of Ethics requires that engineers shall [h]old paramount the safety, health, and welfare of the public"[14] - but does any such obligation fall on their (usually) corporate employers? Moreover, the NSPE Code speaks only of "the public," which is an anonymous, undefined mass of human beings removed from direct knowledge of the individual engineer. Such a public is not a fellowship: it lacks the bonding of speech and the communal sharing of nature's bounty to which Cicero refers in his discussion. It is little wonder, then, that this first canon of the NSPE Code, intended to be the bedrock first principle, becomes the one most easily violated or ignored. And what relevance does such a public have for the student tempted to cheat? The student exists in a world apart. But Cicero's emphasis on "the bonding of reason and speech" points to the primacy of honesty in what we say and do: it is essential to our fellowship in humanity and to our nature as being who have the ability to make moral judgments. For it is indeed our reason that makes us seek truth, fellowship, and moral integrity.

The next major level of fellowship Cicero discusses is the really central one: that of the city. This is something not even recognized in the NSPE Code of Ethics. It may indeed be tempting to dismiss it as irrelevant to the modern world, since ancient Rome was a city-state, and the closest political equivalent today is the nation-state, whose laws provide the context for any company to do business. But Cicero does not point only to the legal or political aspect. Instead, in the city the citizens share "the forum, temples, porticoes and roads" as well as laws, rights, and legal and political institutions [15]. Thus the city is, above all, a place in which citizens meet and interact with one another, worship, and debate the laws together. It is a place that 
defines an individual's identity. When we weaken the bonds to our localities, we risk taking away what can make the fellowship of humanity concrete and personal. Indeed, all that will be left then is the anonymous public.

But there is another point worth making as well. For Cicero specifically mentions "those business and commercial transactions that many of [the citizens] make with many others as being among the ties that citizens form among themselves [16]. This is important, for it clearly subordinates the business (and for us the industrial) interests to the larger fellowship of the city. There is, then, a determinate obligation of the businessman to subordinate his self-interest to the larger common good of the city. This flies in the face of much popular ideology of capitalism today, yet it is closer to the moral philosophy of Adam Smith's Theory of Moral Sentiments (1759), the book that preceded the now more famous Wealth of nations (1776), which became the foundation of modern economic theory. Thus the fellowship of the city brings home the necessity not to pollute our water or air, or to poison the soil: for it is the air our friends in the community breathe, the water both we and they drink, the soil nourishing the crops all of us eat. Only when it is an anonymous public who suffers is such behavior a possibility. But the city is not anonymous; Cicero's point remains valid even in today's quite different world. We belong to the city in which we live: its interest is our interest, rather than our self-interest being the determination of the city's. Getting students to recognize this would go far toward reducing the emphasis on personal success that contributes to both professional misconduct and the sense of cheating being permissible as a means to academic "success."

The subordination of the company to the city would also correct an otherwise too easy identification of the employee's interest with the employer's. The fourth canon in the NSPE Code of Ethics requires that professional engineers shall "act for each employer or client as faithful agents or trustees [14]". Certainly any employment relationship requires a level of trust such as this canon reflects. Yet its elaboration in the Rules of Practice focuses on avoiding conflicts of interest; the problem of a conflict between an employer's demands and the law or the public safety is treated under the first canon, where it is made clear that the engineer is to place the public's welfare ahead of the employer's. Yet how easy is this to do in practice? How clear is the concept of primary obligation to the public, when the public is only abstract, and the company for which one works is the only community that seems to matter? The absence of the city as the primary institutional focus of loyalty in our moral practice is what permits the company to emerge as the only true community the engineer knows. When engineering students see this as a fact of life, it is difficult to make them see academic dishonesty as fundamentally wrong, as long as it does not hurt their chances for success, or those of the company. The stage is set for professional misconduct.
The final levels of fellowship Cicero treats are those of the family and of friends. At first glance, these appear to be consistent with students' own perceptions: they are the strongest ties to others, and students consistently report the closeness of the families and friends, ranking them above all other loyalties. Yet Cicero's criterion of friendship may give us pause: "For honorableness...moves us, even if we see it in someone else, and makes us friends with him in whom it resides [17]". One's friends, therefore, are not simply those among whom one shares certain interests and activities, but those with whom one shares virtue, the moral excellence rooted in a sense of honor. Students are necessarily at an age when they are seeking deeper friendships for the first time in their lives, and their sense of the primary importance of virtue in their relationships may not be well developed. Thus it is very easy for students to develop a code of conduct for themselves that places loyalty to their peers, with whom they share the same interests, ahead of honorableness. In such cases, student fellowship itself will not necessarily inhibit academic dishonesty, and may well foster its spread. But such an outcome is the result of forgetting Cicero's ranking of human fellowship: one's friends are last in the scale, although the strongest ties. Humanity and the city demand greater allegiance.

To be sure, the NSPE Code of Ethics now addresses the place of the peer community for practicing engineers. Indeed, it emphasizes the concept of honor: engineers shall "conduct themselves honorably, responsibly, ethically, and lawfully so as to enhance the honor, reputation, and usefulness of the profession [14]". This is a valuable addition, for it attempts to create a sense of community among engineers and to use that to reinforce a sense of honor that will lead to ethical conduct. It offers the clearest sense of community larger than the company employing an engineer. As such, it constitutes the best hope for persuading engineering students that they do indeed have responsibilities outside their place of employment. Yet we would argue that it does not go far enough. For unless we can reclaim a sense of humanity as entailing a moral nature and specific obligations to all human beings, together with a renewed vitality of our cities as the concrete communities in which we actually live, codes of ethics are likely to be less effective than we would like. But this means that all of us must work to restore our cities as functioning communities, as contexts for moral practice. Only then will the theoretical arguments of moral philosophers make sense to our students, and have any chance of informing their academic practices now or their professional practices in their future careers. Only when life in community displaces material success as the principal criterion of the good life will ethical principles have much meaning.

\section{Practical ImPlications}

The premise of this paper has been that professional codes of ethics have little inherent meaning for our students as our 
modern society rejects the notion of a moral obligation to a "community" as a measure of success. Rather we measure success by the accumulation of material goods, the size of our salary, etc. Professional codes, which tell us how to behave but provide no rationale for this, are based on the presumption that an obligation to a broader community already exists. This may not be the case at all with our students. Therefore, we present a number of practical steps that could be taken to increase the sense of community among undergraduate engineering students.

Within the classroom there are a number of different steps that instructors can take to increase the sense of community within their students. One option is to create case studies that relate the course material to societal issues. Case-based learning provides opportunities for students to debate opposing views that often incorporate a moral component [18]. As part of an assignment, students could be asked to interview an engineering professional about the interface between their job and societal issues. Invited speakers could accomplish a similar goal. Engineering faculty could also play an important role by reinforcing the importance of social sciences and humanities courses when students complain that these courses are mere "fluff". Perhaps the best way to bring community into the classroom is to institute cooperative learning strategies [19]. These techniques have been shown to not only enhance student learning but also teamwork skills and appreciation of differing viewpoints.

At the institutional level we would encourage universities to implement base cooperative learning groups, known as "Living/Learning" communities at those institutions where they already exist. These are groups formed among students from different disciplines in the freshmen year and largely maintained as the students matriculate through the institution. Direct contact with students from other disciplines would likely have a significant effect on engineering students' perceptions about their role in society and the importance of other disciplines and points of view.

Engineering students should also be encouraged to participate in programs that allow them to widen their experiences. These may include research opportunities, intern/co-op work, outreach programs and service-based learning. Engineering students might also be included in institution-wide advisory boards so that they are given the opportunity to participate directly in the administration of their community.

Finally we might consider changes at the level of engineering education in general. Here the challenge is much greater given the effort required to make such large and sweeping changes. However, we would suggest that the introduction of ABET Engineering Criteria 2000 is already making positive steps. Several of the program outcomes (AK) specified by EC 2000 directly introduce the concept of a moral obligation to community (e.g. life-long learning, professional and ethical responsibility, impact of engineering on society). A commitment to these program outcomes and appropriate assessment could have a significant impact on the educational opportunities for students to develop a sense of moral obligation. A more radical approach is to consider the idea of making engineering a true professional degree along the lines of the medical and legal profession such that students would be required to attend an engineering school after obtaining their bachelor's degree. While such an approach introduces myriad logistical problems, it would provide students with more opportunities to interact with non-engineering students in "pre-engineering" programs and would enhance the idea of the engineering profession as a community.

\section{Conclusions}

Through this thought paper we have attempted to show that traditional moral philosophy can provide insight into preparing engineering students for ethical professional practice. We have defined a moral obligation to community at a number of levels including humanity, the city, the profession and peers. Further, we have made the case that the obligation to one's city is perhaps the most important and to one's profession the most immediate. However, a reliance on professional codes of ethics to ensure the ethical behavior of new engineers may miss the mark as these codes presume the existence of a sense of community among its adherents. To the contrary, many students today lack a sense of belonging to any community other than their peers. We have attempted to identify a number of approaches that can be taken by instructors, administrators and the engineering education community in general to address this lack of a sense of belonging to a broader community.

\section{REFERENCES}

1 Harp, J. and Taietz, P., "Academic Integrity and Social Structure: A study of cheating among college students," Social Problems ${ }_{2} 13,1966$, pp. 365373.

2 Bowers, W.J., Student Dishonesty and its Control in College. Bureau of Applied Social Research, Columbia University, 1964.

3 McCabe, D. L., "Classroom Cheating Among Natural Science and Engineering Majors," Science and Engineering Ethics 3, 1997, pp. 433445 .

4 Nonis, S. and C. O. Swift, "An Examination of the Relationship Between Academic Dishonesty and Workplace Dishonesty: A Multicampus Investigation," Journal of Education for Business, 76, 2001, pp. 69-77.

5 Harding, T.S., Carpenter, D.D., Finelli, C.J., and Passow, H.J., "The Influence of Academic Dishonesty on Ethical Decision-Making in the Workplace: A study of engineering students," Proc. 2004 American Society for Engineering Education Annual Conference, Washington, D.C.: ASEE, 2004.

6 Sims, R. L., "The Relationship Between Academic Dishonesty and Unethical Business Practices," Journal of Education for Business, 68, 1993, pp. 207-211.

7 Rest, J. R., "Background: Theory and Research", Moral Development in the Professions: Psychology and Applied Ethics, J. R. Rest and D. Narvaez. Hillsdale, New Jersey: Lawrence Erlbaum Associates, 1994, pp. 1-25. 
8 Keefer, M. and Ashley, K.D., "Case-based Approaches to Professional Ethics: a systematic comparison of students' and ethicists' moral reasoning," Journal of Moral Education, 30, n.4, 2001, pp. 377-398.

9 Alasdair McIntyre, After Virtue: A Study in Moral Theory, $2^{\text {nd }}$ ed., Notre Dame: University of Notre Dame Press, 1984, esp. pp.204-21.

10 Aristotle, The Nichomachean Ethics, 1097a, trans. David Ross, rev. ed. by J.L. Ackrill and J.O. Urmson, Oxford: Oxford University Press, 1980, p.12.

11 Ross, Introduction to The Nichomachean Ethics, 1097a, rev. ed. by J.L. Ackrill and J.O. Urmson, Oxford: Oxford University Press, 1980, pp.xxxxi.

12 Marcus Tullius Cicero,On Duties, ed. and trans. M.T. Griffin and E.M. Atkins, Cambridge: Cambridge University Press, 1991, par..50, p.21.

13 Marcus Tullius Cicero,On Duties, ed. and trans. M.T. Griffin and E.M. Atkins, Cambridge: Cambridge University Press, 1991, pars. 51-52, p.22.

14 National Society of Professional Engineers, NSPE Code of Ethics for Engineers (published at Www.nspe.org/ethics/ch 1-code.asp), 2002, p.1.

15 Marcus Tullius Cicero,On Duties, ed. and trans. M.T. Griffin and E.M. Atkins, Cambridge: Cambridge University Press, 1991, par. 53, p.22.

16 Marcus Tullius Cicero,On Duties, ed. and trans. M.T. Griffin and E.M. Atkins, Cambridge: Cambridge University Press, 1991, par.53, p.23.

17 Marcus Tullius Cicero,On Duties, ed. and trans. M.T. Griffin and E.M. Atkins, Cambridge: Cambridge University Press, 1991, par.55, p.23.

18 Fisch, L., "Triggering Discussions on Ethics and Values: Cases and Innovative Case Variations," Innovative Higher Education, 22, 1997, pp. 117-134.

19 Johnson, D.W., Johnson, R.T., and Smith, K.A., Active Learning: Cooperation in the College Classroom, Edina, MN: Interaction Book, 1991. 